\title{
HUMOR DALAM MAJALAH DJAKA LODANG (Kajian Bentuk Humor)
}

\author{
Siti Mulyani \\ FBS Universitas Negeri Yogyakarta
}

\begin{abstract}
Abstrak
The use of puns to express humor in Djaka Lodang, a Javanese magazine, is a language phenomenon of language use that is interesting to study. This research study aims to (1) describe sections containing humorous discourses in Djaka Lodang, and (2) describe the forms of the humorous discourses.

This study employed the descriptive approach. The data sources were Djaka Lodang published in the period of January to March 2003. The research data were segments of discourse containing humorous elements. The data were collected by reading and recording by means of the discourse analysis technique. The data validity was assessed through semantic validity. The data reliability was assessed by reading and rereading (intra-rater reliability). The data were analyzed by using the descriptive technique comprising induction and comparison, categorization, tabulation, and inference making.

The research findings show that of 32 sections available in Djaka Lodang 18 sections contain humorous discourses. The 18 sections are (1) Cerita Rakyat, (2) Srumuwus, (3) Wawasan Droning Negara, (4) Wawasan Jaban Ranglcah, (5) Pagelaran, (6) Profil, (7) Sketsa, (8) Pedhalangan, (9) Lem bar Agama, (10) Macapat, (11) Seninjong, (12) Cerita Sambung, (13) Mendhowan, (14) Pengalamanku, (15) Cerita Cekak, (16) Wacan Bocah, (17) Tetepungan, and (18) Dhat Nyeng. There are seven forms of the humorous discourses, namely description, story, topic sentence, poem, magic spell, trapping expression, and pun.
\end{abstract}

Key word: the forms of humor in Djaka Lodang

\section{A. Pendahuluan}

\section{Latar Belakang Masalah}

Humor dalam kehidupan suatu masyarakat memiliki peranan sebagai hiburan. Dengan demikian keberadaannya dapat mengurangi kejenuhan. Suprana (1996) menyatakan bahwa tanpa humor, kehidupan ini terasa kering.

Di samping itu, humor juga mempunyai manfaat seperti yang diungkapkan Ancok (1996) bahwa dengan menikmati humor segala macam beban, frustasi dan keluh-kesah dapat terkurangi. Akibat lebih lanjut manusia akan dapat memperoleh kejernihan pendangan se- hingga yang bersangku tan dapat membed a kan sesuatu itu benar atau salah. Hal tersebut dapat terjadi karena humor dapat menyalurkan ketegangan batin yang menyangkut ketimpangan norma masyarakat dan ketegangan itu dapat dikendorkan melalui tawa (Wijana, 1996)

Masyarakat modern lebih menyadari arti humor dan mengembangkannya dari pada masyarakat yang belum maju atau sedang berkembang. Sebagai contoh di Amerika Serikat telah terbit lebih dari 500 buku tentang humor. Ungkapan atau cerita humor yang ada 
bersumber dari seluruh aspek kehidupan (Bakhrun Yunus, 1986).

Masyarakat Jawa telah lama mengenal humor, sebagai misal dalam pentas kesenian tradisional. Widati (1987) menyebutkan bahwa episode humor yang terdapat dalam wayang disebut garagara, dalam ludruk disebut banyolan, dalam kethoprak disebut dhegelan.

Dewasa ini dalam mass media marak memunculkan sesuatu yang mengandung unsur humor, baik dalam media elektronik maupun dalam media cetak. Hal itu tampak pada stasiun televisi maupun radio yang menayangkan acara-acara yang mengandung unsur humor, sebagai misal Kethoprak humor oleh RCTI, Srimulat oleh Indosiar, dan Obrolan Angkring oleh TVRI Yogyakarta.

Sementara itu, dalam media cetak terdapat kartun yang mengandung wacana humor, dalam kala warti Djaka Lodang muncul rubrik Pengalamanku dan rubrik Dhat Nyeng. Kedua rubrik itu juga mengandung unsur-unsur humor. Kalau dicermati wacana humor itu berupa permainan bahasa dan itu tidak bisa dihindarkan oleh setiap orang. Hal tersebut sesuai dengan pendapat Crystal (1998) yang menyebutkan bahwa setiap orang berma in dengan bahasanya atau merespon permainan bahasa. Sementara itu persepsi orang terhadap hal itu bermacam-macam, ada yang hanya terhibur tetapi ada juga yang benar-benar terobsesi dengan hal itu.

Permainan bahasa dalam rangka memunculkan humor dalam majalah berbahasa Jawa Djaka Lodang merupakan fenomena pemakaian bahasa yang menarik untuk diteliti.

\section{Tujuan Penelitian}

Penelitian humor dalam majalah Djaka Lodang ini diharapkan bermanfaat untuk melengkapi penelitian terhadap wacana humor, karena penelitian terdahulu belum ada yang memberikan bentuk humor dalam majalah Djaka Lodang. Di samping itu, sebagai wujud nyata pendokumentasian fenomena pemakaian bahasa Jawa yang muncul di tengah masyarakat Jawa.

Penelitian ini bertujuan untuk (1) memerikan rubrik-rubrik di dalam majalah Djaka Lodang yang mengandung humor dan (2) mendeskripsikan bentukbentuk wacana humor yang terkandung di dalamnya.

\section{Landasan Teori}

Humor dapat digunakan sebagai alat untuk mengekspresikan gagasan, pikiran, atau perasaan seseorang sehingga sasaran humor akan tersentuh perasaannya. Sebagai akibatnya yang bersangkutan dapat tersenyum, tertawa atau geli. Hal itu senada dengan pendapat Raskin (1994) yang menyatakan bahwa humor merupakan rangsangan yang mempunyai potensi memancing tawa.

Lebih lanjut Rustono (1998) menyatakan bahwa humor tidaklah sekedar berupa penyebab munculnya reaksi senyum atau tawa, tetapi juga dapat berupa kemampuan menghibur dan menggelikan melalui ujaran atau tulisan.

Berdasarkan teori psikologi humor konsep penciptaan humor pada pokoknya bertumpu pada tiga teori, ketiga teori itu adalah teori ketidakselarasan, teori pertentangan, dan teori pembebasan (Wijana, 1996, Wilson, 1979). Berdasarkan teori ketidakselarasan humor dimunculkan dengan menggabungkan dua makna atau penafsiran yang berbeda ke dalam objek yang sama yang komplek. Ketidakselarasan bagianbagian itu dipersepsi oleh penikmatnya secara tiba-tiba. Ketidakselarasan tersebut dapat juga dipandang sebagai suatu pertentangan. Dengan terselesaikannya pertentangan atau ketidakselarasan 
tersebut menurut teori pembebasan manusia akan merasakan adanya kebebasan.

\section{Bentuk Humor}

Jika dilihat penampilan atau formatnya humor terdiri dari beberapa bentuk. Yunus (1997) mengatakan bahwa berdasarkan bentuknya humor ada beberapa bentuk, diantaranya; humor sebaris, humor dua baris, humor dialog, humor dalam bentuk cerita, humor kalimat topik, humor puisi, humor keseleo lidah (salah ucap), humor permainan kata, humor interupsi, humor tolak bala, humor surat, humor kuliah, humor salah intonasi, humor ungkapan penjerat, humor statistik, humor pematah, humor balik dan humor silang kata.

Yang dimaksud dengan humor sebaris adalah humor yang diekspresikan dengan satu baris atau satu kalimat saja. Humor dua baris adalah humor yang terdiri dari dua kalimat, sedang yang dimaksud dengan humor dialog merupakan humor yang berbentuk dialog antartokoh. Humor dalam bentuk cerita merupakan kombinasi antar narasi yang bersifat deskriptif dengan dialog. Humor kalimat topik berbentuk satu atau dua kalimat yang isinya berkaitan dengan situasi dan kondisi yang belum lama berlangsung di masyarakat. $\mathrm{Nu}-$ ansa lucu humor ini kurang kuat tetapi orang dapat tertawa karena mereka masih dapat mengkaitkan dengan peristiwa yang terjadi di sekitar mereka.

Di samping itu, humor juga dapat berbentuk puisi, dalam hal ini humor ditampilkan dalam bentuk syair, pantun, peribahasa atau dalam bentuk parodi. Humor keseleo lidah (salah ucap) merupakan humor yang berbentuk ungkapan-ungkapan yang sudah lazim dibelokkan ucapannya sehingga menimbulkan kelucuan, baik karena maknanya yang berubah ataupun kar- ena bentuknya yang sudah tidak bermakna. Humor ini juga sering disebut humor plesetan. Humor permaian kata (pun) adalah humor yang memanfaatkan kata-kata yang mempunyai kemiripan pengucapan tetapi kata-kata tersebut makna dan atau ejaannya berbeda.

Humor tolak bala adalah humor yang bertujuan menghentikan perbuatan atau tingkah laku seseorang yang mengejek atau meresahkan orang lain. Humor ini berbentuk pernyataan dan ada interupsi yang berupa perbuatan, teriakan, ejekan, atau pemyataan yang bukan-bukan(aneh). Salah intonasi juga bisa merupakan bentuk humor, dalam hal ini salah intonasi yang dapat berakibat salah makna atau berubahnya pengertian. Humor merupakan ungkapan penjerat berbentuk pernyataan atau cerita yang terdiri dari beberapa kalimat, kalimat pertama mempunyai daya tarik karena kalimat itu mengandung ungkapan yang sudah populer di masyarakat sehingga dapat menggelitik rasa lucu.

Humor pematah bertujuan untuk mematahkan pertanyaan orang lain secara 'agak kasar', di sini penanya mengajukan sebuah pertanyaan dan dijawab dengan dua kalimat atau pemyataan berturut-turut dengan jeda yang cukup panjang. Humor balik (humor silang kata) biasanya terdiri dari dua buah frasa atau beberapa kata atau suku kata yang diubah atau dibalik susunannya dalam frasa pertama, frasa kedua merupakan frasa yang berterima dari segi bentuk, dan memiliki makna yang jelas.

\section{B. Metode Penelitian}

Penelitian ini mempergunakan pendekatan deskriptif. Sumber data penelitian ini adalah majalah Djaka Lodang yang telah diterbitkan pada bulan Januari sampai dengan Mei 2003. Objek penelitian ini adalah satuan lingual yang mengandung unsur humor. Pengumpu- 
lan data dilakukan dengan pembacaan dan pencatatan lewat teknik analisis wacana. Piranti yang dipergunakan untuk menjaring data adalah referensi, inferensi, analogi, perbandingan, dan pengetahuan tentang dunia (Brown \& Yule, 1983).

Validitas data dicapai lewat validitas semantis dalam hal ini pemaknaan satuan lingual sesuai dengan konteksnya. Reliabilitas data pada penelitian ini dilakukan dengan cara baca-dan- kaji ulang (intra-rater).

Analisis data pada penefitian ini dilakukan dengan teknik deskriptif dengan langkah-langkah komparatif, kategorisasi, tabulasi dan inferensi. Teknik komparatif dipergunakan untuk membandingkan data-data yang diperoleh terkait dengan bentuk humor yang terkandung dalam wacana dalam majalah Djaka Lodang. Teknik kategorisasi dipergunakan untuk merangkum seluruh data yang diperoleh dan teknik inferensi untuk menginferensikan hasil penelitian berdasarkan kategori-kategori yang diperoleh.

\section{Hasil Penelitian dan Pembahasan \\ 1. Hasil Penelitian}

Dari data yang terkumpul dapat diketahui rubrik-rubrik dalam majalah Djaka Lodang yang memuat wacana humor beserta bentuk wacana humomya. Hal itu tampak pada tabel berikut ini.

\section{a. Rubrik Asal Wacana Humor}

Rubrik-rubrik dalam majalah Djaka Lodang yang memuat wacana humor tampak pada tabel di bawah ini.
Tabel 1: Rubrik Asal Wacana Humor

\begin{tabular}{|c|l|c|c|}
\hline No. & \multicolumn{1}{|c|}{ Rubrik Asal } & Jumlah & Persentase \\
\hline 1. & Cerita Rakyat & 1 & 0,4 \\
\hline 2. & Srumuwus & 2 & 0,8 \\
\hline 3. & $\begin{array}{l}\text { Wawasan Jroning } \\
\text { Negara }\end{array}$ & 8 & 3,4 \\
\hline 4. & $\begin{array}{l}\text { Wawasan Jaban } \\
\text { Rangkah }\end{array}$ & 5. & 3 \\
\hline 5. & Pagclaran & 3 & 1,3 \\
\hline 6. & Profil & 1 & 0,4 \\
\hline 7. & Sketsa & 3 & 1,3 \\
\hline 8. & Pedhalangan & 11 & 4,6 \\
\hline 9. & Lembar Agama & 1 & 0,4 \\
\hline 10. & Macapat & 20 & 8,4 \\
\hline 11. & Seninjong & 13 & 5,5 \\
\hline 12. & Cerita Sambung & 1 & 0,4 \\
\hline 13. & Menddhouan & 7 & 3 \\
\hline 14. & Pengalamanku & 67 & 28,3 \\
\hline 15. & Cerita Cekak & 5 & 2,1 \\
\hline 16. & Wacan Bocah & 3 & 1,3 \\
\hline 17. & Tetepungan & 2 & 0,8 \\
\hline 18. & Dhat Nyeng & 82 & 34,6 \\
\hline & Jumlah & 237 & 100 \\
\hline & & & \\
\hline
\end{tabular}

\section{b. Bentuk Wacana Humor}

Dari data yang terkumpul bentukbentuk wacana humor yang termuat dalam majalah Djaka Lodang nampak pada tabel berikut ini:

Tabel 2: Bentuk Wacana Humor

\begin{tabular}{|c|c|c|c|c|c|c|c|c|c|}
\hline \multirow[t]{2}{*}{ No. } & \multirow[t]{2}{*}{ Rubrik Asal } & \multicolumn{7}{|c|}{$\begin{array}{c}\text { Bentuk Wacana } \\
\text { Humor }\end{array}$} & \multirow[t]{2}{*}{ Jumlah } \\
\hline & & 1 & 2 & 3 & 4 & 5 & 6 & 7 & \\
\hline 1. & Cerita Rakyat & - & 1 & - & - & - & - & - & 1 \\
\hline 2. & Srumuwus & - & - & - & - & - & 1 & 1 & 2 \\
\hline 3. & $\begin{array}{l}\text { Wanvasan } \\
\text { Jroning } \\
\text { Nagara }\end{array}$ & 1 & - & - & - & 3 & 3 & 1 & 8 \\
\hline 4. & $\begin{array}{l}\text { Wawasan } \\
\text { Njaban } \\
\text { Rangkah }\end{array}$ & 5 & - & - & - & 1 & 1 & - & 7 \\
\hline 5. & Pagelaran & - & 1 & - & - & - & 1 & 1 & 3 \\
\hline 6. & Profil & - & 1 & . & - & - & - & - & 1 \\
\hline 7. & Sketsa & 2 & - & - & - & - & - & 2 & 3 \\
\hline 8. & Pedhalangan & - & 11 & - & - & - & - & - & 11 \\
\hline 9. & $\begin{array}{l}\text { Lembar } \\
\text { Agama }\end{array}$ & - & - & - & - & - & - & 1 & 1 \\
\hline 10. & Macapat & - & - & - & 20 & - & - & - & 20 \\
\hline 11. & Seninjong & - & 12 & - & - & 1 & - & - & 13 \\
\hline 12. & $\begin{array}{l}\text { Cerita } \\
\text { Sambung }\end{array}$ & - & 1 & - & - & - & - & $\cdot$ & 1 \\
\hline 13. & Mendhowan & - & 7 & - & - & - & $=$ & - & 7 \\
\hline 14. & Pengalamanku & - & 67 & - & - & - & - & - & 67 \\
\hline
\end{tabular}




\begin{tabular}{|c|l|c|c|c|c|c|c|c|c|}
\hline 15. & Cerita Cekak & - & 5 & - & - & - & - & - & 5 \\
\hline 16. & Wacan Bocah & - & 3 & - & - & - & - & - & 3 \\
\hline 17. & Tetepungan & - & 2 & - & - & - & - & - & 2 \\
\hline 18 & Dhat Nyeng & - & - & 82 & - & - & - & - & 82 \\
\hline \multicolumn{1}{|c|}{ Jumlah } & 8 & 111 & 82 & 20 & 5 & 7 & 4 & 237 \\
\hline
\end{tabular}

Keterangan:

1. Deskripsi

2. Cerita

3. Kalimat Topik

4. Puisi

5. Tolak Bala

6. Ungkapan Penjerat

7. Permainan Kata

\section{Pembahasan}

a. Rubrik Asal Humor

Dari data yang terkumpul dapat diketahui bahwa tidak semua rubrik yang terkandung dalam majalah Djaka Lodang memuat wacana humor. Dari ke-32 rubrik yang ada pada majalah Djaka Lodang hanya 18 rubrik saja yang mengandung unsur-unsur humor.

Rubrik-rubrik dalam majalah Djaka Lodang yang memuat wacana humor adalah (1) rubrik Cerita Rakyat sebanyak 1 wacana $(0,4 \%)$, (2) rubrik Srumuwus sebanyak 2 wacana $(0,8 \%)$, (3) rubrik Wawasan Jeroning Negara sebanyak 8 wacana $(3,4 \%)$, (4) rubrik Wawasan Jaban Negara sebanyak 7 wacana (3\%), (5) rubrik Pagelaran sebanyak 3 wacana $(1,3$ \%), (6) rubrik Profil sebanyak 1 wacana $((0,4 \%),(7)$ rubrik Sketsa sebanyak 1 wacana 3 wacana $(1,3 \%)$, (8) rubrik Pedhalangan sebanyak 11 wacana $(4,6 \%),(9)$ rubrik Lembar Agama sebanyak 1 wacana $(0,4 \%),(10)$ rubrik Macapat sebanyak 20 wacana $(8,4 \%),(11)$ rubrik Seninjong sebanyak 13 wacana (5,5\%), (12) rubrik Cerita Sambung sebanyak 1 wacana $(0,4$ $\%)$, (13) rubrik Mendhowan sebanyak 7 wacana (3\%), (14) rubrik Pengelamanku sebanyak 67 wacana $(28,3 \%),(15)$ rubrik Cerita Cekak sebanyak 5 wacana (2,1\%), (16) rubrik Wacan Bocah sebanyak 3 wacana $(1,3 \%),(17)$ rubrik Tetepungan se- banyak 2 wacana $(0,8 \%)$, dan (18) rubrik Dhat Nyeng sebanyak 82 wacana $(34,6$ $\%)$.

Lebih lanjut dapat dijelaskan bahwa dari 18 rubrik dalam majalah Djaka Lodang rubrik yang khusus memuat wacana-wacana humor adalah rubrik Pengalamanku dan Dhat Nyeng (dalam sekali terbit mengandung lebih dari 3 wacana humor).

Sedang rubrik dalam majalah Djaka Lodang yang tidak mengandung wacana humor adalah rubrik Jagading Lelembut, Wanita lan Kulawarga, Lumantar Jamu Istimewa Artikel, Layang Para Maos, Lembar Istimewa, Sastra lan Budaya, Geguritan, Oh... Lelakon, Konsultasi Para Normal, Remaja, Dirawat Intensif ing Klinik Bambang Yuwono, dan rubrik Satleraman.

\section{b. Bentuk Wacana Humor}

Wacana humor yang terkandung dalam majalah Djaka Lodang bentuknya bervariasi. Dari data yang terkumpul ada tujuh (7) bentuk wacana humor. Berturut-turut bentuk wacana humor yang frekuensinya paling banyak sampai yang paling sedikit yang termuat dalam majalah Djaka Lodang sebagai berikut: wacana humor berbentuk cerita 111 wacana $(46,8 \%)$, berbentuk kalimat topik sebanyak 82 wacana $(34,5 \%)$, berbentuk puisi sebanyak 20 wacana $(8,4 \%)$, berbentuk deskripsi sebanyak 8 wacana $(3,3 \%)$, berbentuk ungkapan penjerat sebanyak 7 wacana $(2,9 \%)$, berbventuk tolak bala sebanyak 6 wacana $(2,5 \%)$, dan berbentuk permainan kata sebanyak 4 wacana (1,6\%).

Di samping itu, dari tabel 2 dapat diketahui bahwa bentuk wacana humor yang banyak terkandung dalam majalah Djaka Lodang adalah wacana humor yang berbentuk cerita. Humor berbentuk cerita inipun dapat muncul di berbagai rubrik yang ada dalam majalah Djaka Lodang. Humor itu paling banyak 
terkandung dalam rubrik Pengalamanku sebanyak 67 wacana (60\%), muncul juga dalam rubrik Seninjong, Pedhalangan, Mendhowan, Cerita Cekak, Wacan Bocah, Tetepungan, Cerita Rakyat, Pagelaran, Profil, dan Cerita Sambung.

Hal yang menarik bahwa humor berbentuk kalimat topik termuat dalam majalah Djaka Lodang (dalam hal ini 82 wacana/35 \% dari keseluruhan wacana humor yang termuat dalam majalah Djaka Lodang) hanya termuat dalam rubrik Dhat Nyeng. Demikian juga halnya dengan humor yang berbentuk puisi, humor itu cukup banyak ditemukan dalam majalah Djaka Lodang yaitu 20 wacana/8,5 \% dari keseluruhan wacana dan itu hanya ditemukan dalam rubrik Macapat.

Berikut ini akan dipaparkan beberapa contoh wacana humor yang termuat dalam majalah Djaka Lodang dari berbagai bentuknya. Humor berbentuk deskripsi nampak pada kutipan di bawah ini.

Dene jaman iki kok isil: akeh garagara, ana gelutan, obongobongan, bom njeblug Ian sapanunggaalane, mesthine ora neng Yogyakarta maneh. Ngendi ana garagara kok bola-bali.Tumrape wong Mataram, mesthine mung kari ngantu-antu babaring lelakon. Dene pancen ana siji-loro Wong Mataram sing isih kangslupan iblis ing jaman iki, amarga... ora gelem maca sejarah

'Adapun di saat sekarang masih ada gara-gara, ada perkelaian, bakar-bakaran, meletusnya born Ian lain sebagainya, mestinya tidak di Yogyakarta. Tidak ada adegan garagara terjadi berulang kali. Untuk orang Mataram, mestinya tinggal menunggu akhir dari suatu kejadian, kalau memang saat ini masih ada satu dua orang Mataram yang masih kemasukan setan, karena tidak mau membaca sejarah'(DL. No. 37/ 2003: 9)

Penggalan wacana di atas berupa paparan yang berisi situasi kondisi sekarang yang penuh kekacauan, misalnya adanya perkelahian, peristiwa bakar-bakaran, born meletus dimanamana. Tentunya keadaan semacam itu tidak akan terjadi di Yogyakarta, karena dalam sejarah peristiwa semacam itu pernah terjadi di Yogyakarta dengan diumpamakan garagara dalam pewayangan. Dengan demikian daerah Istimewa Yogyakarta hanyalah menanti akhir dari semua peristiwa-peristiwa tersebut.

Kelucuan penggalan wacana tersebut terletak pada satuan lingual yang berbunyi "dene pancen ana siji loro wong Mataram isih kaslungpan iblis ing jaman $i k i$, amarga... ora Belem maca sejarah 'Sementara itu jika di jaman sekarang ini ada satu dua orang Mataram yang masih kerasukan iblis, karena tidak mau membaca sejarah' ". Satuan lingual itu menggelitik rasa lucu pembaca karena di situ terkandung makna bahwa orang Mataram itu baik-baik semua, tetapi kalau ada yang yang tidak baik dikarenakan yang bersangk $\mathrm{u}$ tan tidak mau membaca sejarah.

Berikut ini salah satu contoh wacana humor yang berbentuk cerita yang terkandung dalam majalah Djaka Lodang.

Prabu Dasamuka katon ora seneng nyawang wujude Anoman. Sigra dhawuh ma rang Anoman supaya lungguh, awit wis dadi pranatan ing ngendi papan, sing jeneng ngadhep ratu iku ora kena ngadeg, ora kena pethenthangpethentheng, kudu ngajeni ratu. Nanging Anoman malah ndazvakake buntute. Sawise diringkel-ringkel kaya pir, null lungguh. 
"Bareng ngerti yen aku Prabu Dasamuka, kowe ngadeg rumangsa kurang dhuwur, banjur buntutmu mbok ringke!-ringkel dadi dhuwur banget. Kowe madhani aku, drohun!

"Iya awit aku mesthekake bakal kena pidana pati. Dadi upama aku mati, ranging wis klakon madhani karo Prabu Dasamuka".

"Pancen kowe monyet keparat! Mripatmu pantes takcukil!".

"Akududu monyet keparat, jenengku Senggana ya Anoman. Aku dutane Prabu Ramawijaya ratu ing Pancawati. Tekaku mrene diutus ratu Gustiku supaya nyidikake apa kepara nyata Dewi Sinta mapan ing negara Ngalengka"

'Dasamuka terlihat tidak senang melihat wajah Anoman. Segera memerintahkan Anoman supaya duduk, karena sudah menjadi peraturan di semua tempat orang yang sedang menghadap raja tidak boleh sambil berdiri, tidak boleh belagu, harus menghormat raja. Tetapi Anoman malahan memanjangkan ekor. Setelah dilipat-lipat seperti pir, kemudian duduk.

"Setelah mengetahui kalau saya Prabu Dasamuka, kemudian kamu berdiri setelah merasa kurang tinggi, kemudian ekormu kamu lipatlipat jadi tinggi sekali. Kamu ingin menyamai saya, drohun!

"Iya karena saya memastikan akan mendapat hukuman mati. Jadi seandainya saya mati, tetapi sudah berhasil menyamai Prabu Dasamuka"

"Kamu memang monyet keparat! Matamu pantas saya cukil!

"Saya bukan monyet keparat, nama saya Senggana atau Anoman. Saya utusan Prabu Ramawijaya raja Pancawati. Kedatangan saya di sini disuruh raja saya untuk mencari kabar kebenaran apakah Dewi Sinta berada di negara Ngalengka.....' (DL. No. 37/2003: 16).

Penggalan wacana humor di atas dapat dikatakan berbentuk cerita, karena wacana tersebut terdiri dari dua bagian, yakni bagian deskripsi dan bagian dialog. Bagian deskripsi berupa tiga (3) kalimat pertama yang berisi ilustrasi situasi dan kondisi pertemuan antara Prabu Dasamuka dengan Anoman. Pada waktu itu Prabu Dasamuka tidak senang melihat sikap Anoman sewaktu menghadapnya.

Ketidaksenangan itu disebabkan Anoman tidak menggunakan sopan santun/ adat istiadat sewaktu menghadap ratu. Sedang bagian dialog berisi percakapan Prabu Dasamuka dengan Anoman. Tuturan Prabu Dasamuka berisi paparan wujud ketidaksopanan Anoman di hadapan Prabu Dasamuka, hal itu nampak pada ungkapannya berikut ini; "Bareng ngerti yen aku Prabu Dasamuka, kowe ngadeg rumangsa kurang dhuwur, ban jur buntutmu mbokringkel-ringkel dadi dhuwur banget...'Setelah kamu mengetahui bahwa saya Prabu Dasamuka, kamu berdiri, merasa kurang tinggi kemudian ekormu kamu lipat-lipat jadi tinggi sekali...'" Tuturan itu dijawab dengan ungkapan; "Iya awit aku mesthekake bakal kena pidana pati. Dadi upama aku mati, nanging wis klakon madhani karo Prabu Dasamuka 'Iya karena saya sudah dapat memastikan bahwa akan menerima hukuman mati. Jadi seandaainya saya mati, tetapi sudah berhasil menyamai prabu Dasamuka'".

Dialog antara prabu Dasamuka dengan Anomaan tersebut menyebabkan penggalan wacana itu menjadi wacana yang lucu. Kelucuannya tampak dari ungkapan Anoman yang tidak merasa takut seandainya nanti mendapat hukuman mati dari Prabu Dasamuka bahkan 
seandainya matipun Anoman merasa bangga. Hal tersebut nampak dari ungkapannya, "Dadi upama aku mati, nanging wis klakon madhani karo Prabu

Dasamuka seandainya aku mati, tetapi sudah dapat menyamai Prabu Dasamuka'". Ungkapan Anoman itu menambah kadar kelucuan penggalan wacana di atas.

Selanjutnya wacana humor yang berbentuk kalimat topik dapat dilihat dari kutipan di bawah ini.

Rachmawati Soekarno Putri nand-

hesake yen Megawati Soekarno putri mung putra biologise Bung Karna, dudu putra ideologi Bung karno.

Nedya nandhingi nyalon Presidhen 2004.

'Rachmawati Soekarno Putri menegaskan ka la u Megawati Soekarno Putri hanya putra biologisnya Bung Karna, bukan putra ideologi Bung Karna.

Mau menandingi mencalonkan Presiden 2004.(DL No. 39/ 2002: 50)

Kutipan di atas terdiri dari dua (2) kalimat. Kalimat pertama yang berbunyi "Rachmawati Soekarno Putri nandhesake yen Megawati Soekarno Putri mung putra biologis Bung Karoo, dudu putra ideologi Bung karno 'Rachmawati Soekarno Putri menjelaskan bahwa Megawati Soekarno putri hanya merupakan putri biologis Bung Karno, bukan putri ideologinya' merupakan kalimat topik yang masih terkait dengan kabar peristiwa yang belum lama terjadi di tengah-tengah masyarakat. Sedang kalimat kedua merrupakan tanggapan redaksi majalah Djaka Lodang terhadap isi kalimat topik. Bila kedua kalimat tersebut dibaca secara berturutan maka pembaca akan tertawa atau paling tidak tersenyum karena orang dapat mengerti dengan jelas kenapa muncul pernyataan yang tertuang dalam kalimat topik. Tanggapan yang diberikan oleh redaktur juga menyentil rasa lucu pembaca.

Berikut ini adalah contoh wacana humor yang berbentuk puisi, khususnya puisi Jawa tradisional yang biasa disebut tembang Macapat.

neng his tingkat ngagem peci kon neng dhuwur

nadyan isih mudha

sing sandhalan ngisor mesthi donya

yen maido takokna sangalam

'dalam bis kota menggunakan peci disuruh di atas, meskipun masih muda, yang menggunakan sandal pasti di bawah, kalau tidak percaya tanyakan kepada semua orang'(DL No. 51/ 2003: 19)

Kutipan wacana di atas dikatakan berbentuk puisi tradisional Jawa atau tembang macapat yang dalam hal ini tembang Pocong. Bentuk itu tercermin dari jumlah baris dalam satu bait, jumlah suku kata dalam setiap barisnya (guru wilangan) dan vokal akhir untuk setiap barisnya (guru lagunya). Jika dilihat dari jumlah barisnya (guru gatra) wacana di atas terdiri dari empat (4) baris. Jumlah suku kata dalam setiap barisnya (guru wilangan) dan vokal akhir untuk setiap barisnya terurai sebagai berikut; bails pertama terdiri dari 12 suku kata dengan vokal akhir /u/, baris kedua terdiri dari 6 suku kata dengan vokal akhir /a /, baris ketiga terdiri dari 8 suku kata dengan vokal akhir /i/, dan baris keempat terdiri dari 12 suku kata dengan vokal akhir /a/. Karakteristik wacana demikian itu dimiliki oleh tembang Macapat Pocong.

Kelucuan kutipan wacana di atas terletak pada satuan lingual yang berbunyi "neng bis tingkat ngagem peci kon neng ndhuwur 'di dalam bis tingkat menggunakan peci disuruh di atas'" dan satuan lingual 'sing sandhalan ngi- 
sor mesthi 'yang memakai sandal pasti di bawah'". Kedua satuan lingual itu memberitahukan kepada pembaca bahwa di dalam bis kota yang menggunakan peci di atas dan yang menggunakan sandal di bawah. Sebetulnya masyarakat tanpa diberitahupun sudah tahu bahwa kalau menggunakan peci pasti di bagian paling atas dari tubuh manusia, yaitu kepala, hal itu dilakukan baik di dalam bis kota ataupun di mana saja. Demikian juga tanpa diberitahupun masyarakat sudah tahu bahwa sandal itu digunakan pada bagian tubuh manusia paling bawah yaitu kaki. Dengan diberitahukannya sesuatu yang sudah dikatahui umum atau memang begitulah tata cara menggunakan perangkat pakaian (peci dan sandal) membuat wacana itu termasuk dalam wacana lucu.

Berikut ini contoh wacana humor yang berbentuk tolak bala yang terkandung dalam majalah Djaka Lodang.

Mogoke kru angkutan umum ora beda kayo mahasiswa sing mogok mangan. Karepe mung golek perhatian, kareben digatekake. Wong nyatane durung tau ana Wong mogok mangan sing mati. Sing mogok mangan mau wis ngerti, mengkone nek wis ngelih, wetenge kelempit tenan, awak ilang days kekuwatane, mesthi ana sing nggotong tekan rumah sakit. Mesthi njur entuk "dhonor" pangan. Semono uga kru angkutan umum, mogok mung bisa tekan sedina rong diva isih wani. lajal was yen wani mogok seminggu, rong minggu, apa maneh sesasi, kelakon semaput teenan mergane anak bojo ra ana sing makani....

'Mogoknya kru angkutan umum tidak berbeda dengan mahasiswa mogok makan. Maksudnya hanya mencari perhatian, supaya diperhatikan. Pada kenyataannya belum ada orang mogok makan hingga coati. Orang yang mogok makan sudah tahu, nantinya kalau sudah lapar, perut benar-benar kosong, badan kehilangan kekuatan pasti ada yang membawa ke rumah sakit. Kemudian mendapat 'donor' makanan. Demikian juga kru angkutan umum, dapat bertahan mogok hanya mencapai sehari dua hari, Coba saja kalau berani mogok satu minggu dua minggu, apalagi mencapai satu bulan, bisa pinsan beneran karena anak isteri tidak ada yang memberi makan....' (DL No. 36 /2003: 4)

Kutipan penggalan wacana di atas dapat dikategorikan sebagai wacana humor yang berbentuk tolak bala, karena wacana itu mengandung pernyataan yang bertujuan menghentikan perbuatan atau tingkah laku seseorang yang mengejek atau meresahkan orang lain. Bentuk perbuatan yang meresahkan orang lain yang terkandung dalam wacana itu adalah perbuatan yang dilakukan kru angkutan umum yang melakukan mogok tidak mau mengangkut penumpang. Perbuatan itu tentulah meresahkan calon penumpang yang tidak dapat dengan segera sampai di tempat tujuan. Sementara itu, sesuatu yang pasti menghentikan perbuatan para kru angkutan umum adalah kewajiban untuk menghidupi keluarga yang menjadi tanggung jawabnya. Hal itu terungkap dalam satuan lingual berikut ini, "Semono uga kru angkutan umum, mogok mung bisa sedina rong diva isih wani.'Demikian juga kru angkutan umum, mogok hanya bisa bertahan sehari dua hari'. Jajal was yen wani mogok seminggu, rong minggu, apa maneh sesasi, kelakon semaput tenan mergane anak bojo ra ana sing makani, 'Coba saja kalau berani mogok satu minggu, dua minggu, apalagi sampai sebulan, 
benar-benar pingsan karena anak isterinya tidak ada yang memberi makan'.

Di samping hal tersebut di atas, ada juga humor yang terkandung dalam majalah Djaka Lodang yang berbentuk suatu ungkapan penjerat. Dalam wacana humor itu mengandung suatu ungkapan yang populer dalam kehidupan masyarakat. Hal itu tampak pada contoh berikut ini.

Liyane iku, pancen bisa Korea Utara nigunakake rudhal nuklir nanging sepira bobote senjata nuklir Korea Utara ditandhing duweke Amerika serikat. Lamun Amerika Serikat diwarahi dhisik Ian dadi "mata gelap" bisa klakon Korea Utara dadi glepung diajar nuklir cacahe maewii-ewii....

'Selain itu, memang bisa Korea menggunakan rudal nuklir tetapi seberapa perbandingan senjata nuklir Korea Utara jika dibandingkan dengan kepunyaan Amerika Serikat. Seumpama Amerika didahului dan menjadi "mata gelap" bisa jadi Korea Utara menjadi tepung karena diajar nuklir yang jumlahnya beribu-ribu....'(DL No. 52. 2003: 5)

Kutipan di atas berbentuk pernyataan yang mengandung ungkapan yang populer di tengah-tengah masyarakat, ungkapan itu berujud "mata gelap". Pernyataan yang disampaikan dalam kutipan di atas adalah keadaan Korea Utara yang sebenarnya dapat menyerang Amerika Serikat dengan rudal nuklirnya, namun jika hal itu dilakukan maka Korea Utara sendirilah yang akan menderita kekalahan. Hal itu dikarenakan Amerika Serikat kondisinya lebih unggul jika dibandingkan dengan Korea Utara. Apalagi bila Amerika Serikat menjadi "mata gelap", maka Korea Utara akan dihancurkan menjadi tepung. Pernyataan di atas mempunyai daya untuk menggelitik rasa humor pembaca karena isinya tentang kelebihan yang dimiliki oleh suatu negara yang tidak mungkin untuk dilaksanakan, juga disertai ungkapan "mata gelap" yang sudah populer di kehidupan masyarakat.

Di bawah ini contoh wacana humor yang berbentuk permaian kata.

Wektu iki negarane dhewe lagi nandhang prihatin kang gedhe. Kalenggahan Ian adege peprentahan kita moyag-mayig ora sreg mantep, kawibawane mrosot, manunggaale nusa bangsa lan negara (Kesatuan Ian Persatuan) kaancam bubar. Ekonomine morat-morit, reregan ndedel mumbul langit, rakyat cilik njerit nganti pecerit, anehe pejabat wetenge "buncit" marga kakehan dhuwit....

'Sekarang ini negara kita baru menerima musibah yang besar. Kedudukan dan keberadaan pemerintahan kita sedang labil, tidak mantap, kewibawaan merosot, kesatuan dan persatuan bangsa dan negara terancam bubar. Ekonomi kacau, harga-harga melambung, rakyat kecil menjerit, anehnya para pejabat berperut buncit karena kebanyakan uang...'(DL No. 32/ 2003: 19)

Kelucuan penggalan wacana di atas terletak pada satuan lingual yang mengandung kata-kata yang bersuku akhir -rit, kata-kata itu adalah moratmarit 'kacau balau', langit 'langit', njerit 'menjerit', buncit 'buncit', dan dhuwit 'uang'. Satuan lingual yang mengandung kata-kata tersebut memperlihatkan suatu keadaan yang saling bertentangan. Keadaan yang dipertentangkan itu adalah keadaan yang tidak mengenakkan (suatu ketidakmapanan) dengan keadaan yang kelewat enak (kelewat 
mapan) tetapi juga mengandung nuansa makna yang tidak baik. Ketidakmapanan atau kelabilan keadaan itu tercermin pada satuan lingual "ekonomine morat-marit, reregan ndedel mumbul inglangit, rakyat cilik njerit nganti pecerit 'ekonomi yang kacau balau, harga-harga melambung ke langit, rakyat kecil menjerit memilukan' ". Sementara itu keadaan yang dipertentangkan nampak pada satuan lingual "anehe akeh pejabat wetenge "buncit" merga kakehan dhuwit 'anehnya banyak pejabat yang berperut buncit karena kebanyakan uang' ".

Dari hal di atas dapat diketahui dengan jelas adanya keadaan yang bertentangan, pada satu sisi rakyat kecil yang serba kekurangan di pihak lain pejabat yang serba kecukupan. Sudah menjadi rahasia umum bahwa banyak pejabat yang kaya karena korupsi, hal itu tampak pada peringkat 6 tentang korupsi yang dimiliki oleh bangsa Indonesia.

\section{Simpulan}

Rubrik-rubrik yang ada dalam majalah Djaka Lodang sebagian besar memuat wacana humor. Namun ada juga rubrik yang tidak memuat wacana humor, tetapi ada dua rubrik yang khusus disediakan untruk menampung wacana humor, yaitu Pengalamanku dan rubrik Dhat Nyeng.

Jika dilihat dari bentuknya, wacana humor yang terkandung dalam majalah Djaka Lodang ada tujuh (7) macam, yaitu humor berbentuk deskripsi, humor cerita, humor kalimat topik, humor puisi, humor tolak bala, humor ungkapan penjerat, dan humor berbentuk permainan kata. Bentuk humor yang paling banyak muncul adalah humor berbentuk cerita.

\section{Daftar Pustaka}

Ancok, Djamaluddin. 1996. "Humor Juga Alat Kontrol Sosial" dalam Prisma No. 1 Tahun XXV. Jakarta: LP3ES Indonesia. Halaman 78 81.

Brown, Gillian dan George Yule. 1983. Discourse Analysis. Cambridge: Cambridge University Press.

Raskin, Victor. 1944. Semantic Mechanism of Humor. Dodrecht Holland: D. Reidel Publishing Company.

Rustono. 1998. "Implikatur Percakapan Sebagai Penunjang Pengungkapan Humor di dalam Wacana Humor Verbal Lisan Berbahasa Indonesia". Disertasi Universitas Indonesia.

Suprana, Jaya. 1996. “Humor di Tengah Masyarakat" dalam Prisma No. 1 Tahun XXV. Jakarta: PT Pustaka LP3ES Indonesia. Halaman $93-99$.

Wijana, I Dewa Putu. 1998. "Wacana Kartun dalam Bahasa Indonesia" dalam Prisma No. 1 Tahun XXV. Jakarta: PT Pustaka LP3ES Indonesia. Halaman $3-16$.

Wilson, Christopher. 1979. Joke: Form Conteent. Use and Functions. New York: Academic Press.

Yunus, Bakhrum, Yusri Yusuf, dkk. 1997. Jenis dan Fungsi Humor dalam Masyarakat Aceh. Jakarta: Pusat Pembinaan dan Pengembangan Bahasa Departemen Pendidikan dan Kebudayaan. 